\title{
Induction of Dickkopf-1, a Negative Modulator of the Wnt Pathway, Is Required for the Development of Ischemic Neuronal Death
}

\author{
Irene Cappuccio, $, 1,2 *$ Agata Calderone, ${ }^{2 *}$ Carla L. Busceti, ${ }^{3 *}$ Francesca Biagioni, ${ }^{3}$ Fabrizio Pontarelli, ${ }^{3}$ Valeria Bruno,, 3 \\ Marianna Storto, ${ }^{3}$ Georg T. Terstappen, ${ }^{4}$ Giovanni Gaviraghi, ${ }^{4}$ Francesco Fornai, ${ }^{3}$ Giuseppe Battaglia, ${ }^{3}$ \\ Daniela Melchiorri, ${ }^{1}$ Suzanne Zukin, ${ }^{2}$ Ferdinando Nicoletti, ${ }^{1,3}$ and Andrea Caricasole ${ }^{4}$ \\ ${ }^{1}$ Department of Human Physiology and Pharmacology, University of Rome "La Sapienza," 00185 Rome, Italy, ${ }^{2}$ Department of Neuroscience, Albert Einstein \\ College of Medicine, Bronx, New York 10462, ${ }^{3}$ Istituto Neurologico Mediterraneo Neuromed, 86077 Pozzilli, Italy, and ${ }^{4}$ Siena Biotech, 53100 Siena, Italy
}

\begin{abstract}
Expression of Dickkopf-1 (Dkk-1), a secreted protein that negatively modulates the Wnt pathway, was induced in the hippocampus of gerbils and rats subjected to transient global cerebral ischemia as well as in cultured cortical neurons challenged with an excitotoxic pulse. In ischemic animals, the temporal and regional pattern of Dkk-1 expression correlated with the profile of neuronal death, as assessed by Nissl staining and Dkk-1 immunostaining in adjacent hippocampal sections. Treatment of ischemic animals with either Dkk-1 antisense oligonucleotides or lithium ions (which rescue the Wnt pathway acting downstream of the Dkk-1 blockade) protected vulnerable hippocampal neurons against ischemic damage. The same treatments protected cultured cortical neurons against NMDA toxicity. We conclude that induction of Dkk-1 with the ensuing inhibition of the canonical Wnt signaling pathway is required for the development of ischemic and excitotoxic neuronal death.
\end{abstract}

Key words: ischemia; neuron; hippocampus; necrosis; NMDA; lithium

\section{Introduction}

Wnts are a family of secreted glycoproteins that bind to the 7 -transmembrane receptors, Frizzled, and coreceptors that correspond to low-density lipoprotein receptor-related protein 5 (LRP5) and LRP6 (Dale, 1998). Activation of the canonical Wnt signaling pathway leads to inhibition of glycogen synthase kinase- $3 \beta$ (GSK-3 $\beta$ ) by dissociating the enzyme from a multiprotein complex that involves axin, adenomatous polyposis coli, and $\beta$-catenin (Willert and Nusse, 1998) and via phosphorylation of GSK-3 $\beta$ on Ser9 (Chen et al., 2000; Fukumoto et al., 2001). This results in the stabilization of the unphosphorylated form of $\beta$-catenin, which is no longer targeted for degradation by the proteasome and is then made available for its transcriptional function (Hinck et al., 1994; Aberle et al., 1997; Willert and Nusse, 1998). GSK- $3 \beta$ phosphorylates, and thereby regulates, the function of metabolic, signaling, and structural proteins and transcription factors (for review, see Grimes and Jope, 2001).

Recent evidence indicates that abnormalities of Wnt signaling might be involved in human brain diseases, including autism (Wassink et al., 2001), schizophrenia (Cotter et al., 1998; Miyaoka et al., 1999; Dean, 2002), and Alzheimer's disease (De

\footnotetext{
Received Aug. 19, 2004; revised Jan. 20, 2005; accepted Jan. 20, 2005.

*I.C., A.C., and C.L.B. contributed equally to this work.

Correspondence should be addressed to Dr. Ferdinando Nicoletti, Department of Human Physiology and Pharmacology, University of Rome "La Sapienza," Piazzale Aldo Moro 5, 00185 Rome, Italy. E-mail: ferdinandonicoletti@hotmail.com.

DOI:10.1523/JNEUROSCI.5230-04.2005

Copyright $\odot 2005$ Society for Neuroscience $\quad$ 0270-6474/05/252647-11\$15.00/0
}

Ferrari and Inestrosa, 2000; Garrido et al., 2002; Inestrosa et al., 2002; Caricasole et al., 2003, 2004; De Ferrari et al., 2003) and in the development of brain tumors (for review, see Howng et al., 2002). In addition, factors that induce GSK- $3 \beta$ phosphorylation on Ser9, and therefore inhibit the enzyme, support neuronal survival (M. Hashimoto et al., 2002), whereas an increase in activity of GSK-3 $\beta$ promotes neuronal degeneration (Chen et al., 2004). GSK-3 $\beta$ inhibitors, including lithium ions, attenuate neurodegeneration after trophic withdrawal, oxygen-glucose deprivation, excitotoxicity, and focal ischemia (Nonaka and Chuang, 1998; Chalecka-Franaszek and Chuang, 1999; Bhat et al., 2000; Hetman et al., 2000; Xu et al., 2003; Kelly et al., 2004; Ma et al., 2004). Neuroprotection may follow the increased stability of $\beta$-catenin, which either translocates to the nucleus and activates genes that regulate neuronal homeostasis (Willert and Nusse, 1998) or is targeted to synapses (Murase et al., 2002).

The canonical Wnt pathway is negatively modulated by the secreted protein Dickkopf-1 (Dkk-1), which binds to LRPs, thus preventing their interaction with Wnts (Zorn, 2001; Mao et al., 2002; Grotewold and Ruther, 2002a,b). The Dkk-1 gene is a transcriptional target of the tumor-suppressing protein, p53 (Wang et al., 2000), which acts as a major sensor of DNA damage in mammalian cells. An increased expression of p53 may promote either DNA repair or the execution phase of apoptotic death depending on the extent of DNA damage (Hofseth et al., 2004; Slee et al., 2004). Hence, induction of Dkk-1 might represent a component of the sequence of events leading to neuronal death (Caricasole et al., 2003). We recently found an induction of 
Dkk-1 in cultured neurons challenged with $\beta$-amyloid peptide as well as in degenerating neurons of the Alzheimer's brain (Caricasole et al., 2004). We now report that Dkk-1 is also induced in neurons subjected to excitotoxic or ischemic insults and is required for the development of ischemic neuronal damage.

\section{Materials and Methods}

Mixed cortical cultures. Mixed cortical cell cultures containing both neurons and astrocytes were prepared from fetal CD1 mice (Charles River, Calco, Italy) at $14-16 \mathrm{~d}$ of gestation, as described previously (Rose et al., 1992). Briefly, dissociated cortical cells were plated in $15 \mathrm{~mm}$ multiwell vessels (Falcon Primaria, Lincoln Park, NJ) on a layer of confluent astrocytes (7-14 $\mathrm{d}$ in vitro) using a plating medium of MEM-Eagle's salts (supplied glutamine free) supplemented with $10 \%$ heat-inactivated horse serum, $10 \%$ fetal bovine serum, glutamine (2 $\mathrm{mm}$ ), and glucose (final concentration, $21 \mathrm{~mm}$ ). Cultures were kept at $37^{\circ} \mathrm{C}$ in a humidified $5 \%$ $\mathrm{CO}_{2}$ atmosphere. After 3-5 d in vitro, nonneuronal cell division was halted by $1-3 \mathrm{~d}$ of exposure to $10 \mu \mathrm{M}$ cytosine arabinoside, and cultures were shifted to a maintenance medium identical to plating medium but lacking fetal serum. Subsequent partial medium replacement was performed twice each week. Only mature cultures (13-14 $\mathrm{d}$ in vitro) were used for the experiments.

Exposure of cortical cultures to excitatory amino acids, lithium chloride, and Dkk-1 antisense. Brief exposure to NMDA (10 min; 30-60 $\mu \mathrm{M})$ was performed in mixed cortical cultures at room temperature in a HEPES-buffered salt solution containing the following (in $\mathrm{mm}$ ): $120 \mathrm{NaCl}$, $5.4 \mathrm{KCl}, 0.8 \mathrm{MgCl}_{2}, 1.8 \mathrm{CaCl}_{2}, 20$ HEPES, and 15 glucose. After $10 \mathrm{~min}$, the excitotoxin was washed out, and cultures were incubated at $37^{\circ} \mathrm{C}$ for the next $24 \mathrm{~h}$ in medium stock (MEM-Eagle's supplemented with $15.8 \mathrm{~mm} \mathrm{NaHCO}_{3}$ and $<25 \mathrm{~mm}$ glucose). In a set of experiments, "end-capped" phosphorothioate mouse Dkk-1 antisense ( $5^{\prime}$ cgGTCTCTGTGATTTggC- $\left.3^{\prime}\right)$ or sense $\left(5^{\prime}\right.$-gc-

CAAATCACAGAGAccG-3') oligonucleotides (both at $1.5 \mu \mathrm{m}$; Invitrogen, Milan, Italy) were preincubated for $16 \mathrm{~h}$ before performing the NMDA pulse and applied again afterward. In another set of experiments, at the end of the NMDA pulse, cultures were exposed to $10 \mathrm{~mm} \mathrm{LiCl}$ for the next $24 \mathrm{~h}$ and then assessed for excitotoxicity. Finally, in additional experiments, cultures were treated with 10 or $100 \mathrm{ng} / \mathrm{ml}$ human recombinant Dkk-1 (R \& D Systems, Minneapolis, MN), either combined with NMDA or added immediately after the NMDA pulse. In control conditions, Dkk-1 alone was added for 10 min or $24 \mathrm{~h}$. Cultures were assessed for excitotoxic degeneration $24 \mathrm{~h}$ after the NMDA pulse. Protein extracts deriving from sister cultures exposed to sense or antisense were used for assessment of Dkk- 1 expression, $\beta$-catenin, and phosphorylated GSK-3 $\beta$ levels by Western blot analysis 6,8 , and $24 \mathrm{~h}$ after the NMDA pulse.

Assessment of in vitro neuronal injury. Neuronal injury was estimated in all experiments by examination of cultures with phase-contrast microscopy at $100-400 \times, 1 \mathrm{~d}$ after the insult, when the process of cell death was essentially complete. Neuronal damage was quantitatively assessed in all experiments by estimation of dead neurons by trypan blue staining. Stained neurons were counted from three random fields per well. Neuronal injury was also assessed by measuring the activity of lactate dehy-
CA1

CA3
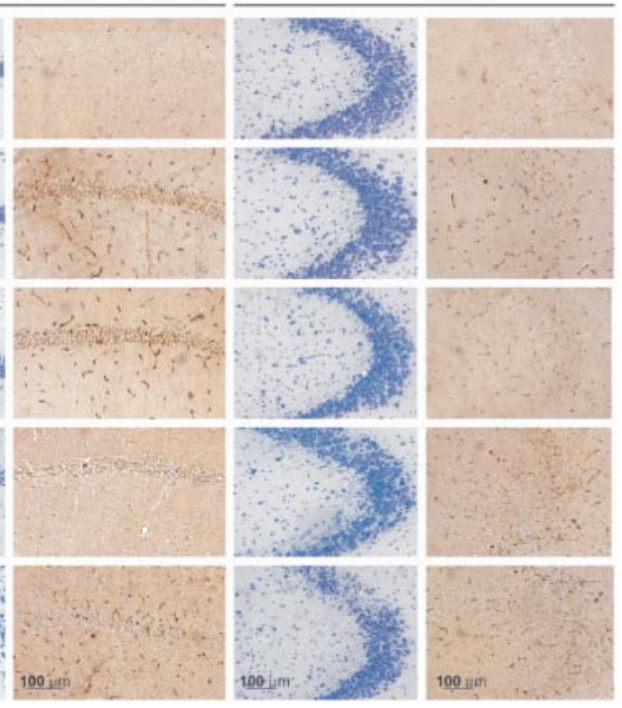

$100 \mathrm{um}$

Niss!

Dkk-1

Nissl

Dkk-1

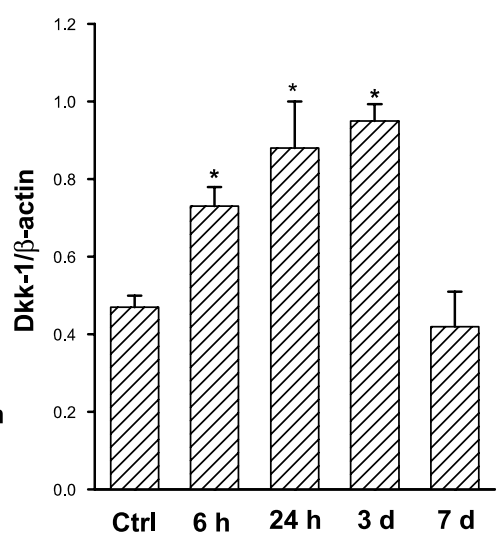

Hippocampus

Figure 1. A, Temporal profile of Dkk-1 expression in the hippocampus of gerbils subjected to $5 \mathrm{~min}$ of global ischemia. Nissl staining and Dkk-1 immunostaining in adjacent sections of the $C A 1$ and $C A 3$ regions of a representative animal at different times 列 in all animals examined $(n=6)$. Western blot analysis of Dkk-1 in the entire hippocampus of ischemic gerbils is shown in $\boldsymbol{B}$. scan analysis. ${ }^{*} p<0.05$; one-way ANOVA plus Fisher's PLSD, when compared with control (Ctrl) values. Sham-operated animals were always considered controls.

drogenase (LDH) released from damaged or destroyed cells into the extracellular medium $1 \mathrm{~d}$ after the addition of the excitotoxin.

Transient global ischemia in mongolian gerbils. Seven-week-old mongolian gerbils (body weight, $70 \pm 6$ g; Charles River) were housed in a temperature- and light-controlled environment with a $12 \mathrm{~h}$ light/dark cycle. Transient global ischemia was induced by clumping both carotids for 5 or $6 \mathrm{~min}$. Body temperature was maintained at $37^{\circ} \mathrm{C}$ (with a rectal thermistor and heat lamp during and after the induction of global ischemia). Sham-operated gerbils in which carotid arteries were not occluded were considered to be controls. Animals were killed at 6 h, $24 \mathrm{~h}$, $3 \mathrm{~d}$, and $7 \mathrm{~d}$ after reperfusion, and brains were processed for histological assessment of neuronal hippocampal degeneration and for immunohistochemistry. To assess the neuroprotective activity of lithium, animals received an intraperitoneal injection of lithium chloride $(1 \mathrm{mEq} / \mathrm{kg}$ every $12 \mathrm{~h}$ ) for $7 \mathrm{~d}$ before the induction of ischemia and for the next 3 or $7 \mathrm{~d}$. Animals were killed $3 \mathrm{~d}$ after ischemia. Separate groups of animals were also treated intracerebroventricularly $(12 \mathrm{nmol} / 2 \mu \mathrm{l}) 24$ and $1 \mathrm{~h}$ before the induction of ischemia and once daily for the next $3 \mathrm{~d}$ with the endcapped phosphorothioate "universal" Dkk-1 antisense (which recognizes rat, mouse, and human Dkk-1) oligonucleotide 5'TAcAGATCTTGGACcAgA-3' or with the phosphorothioate universal 
A
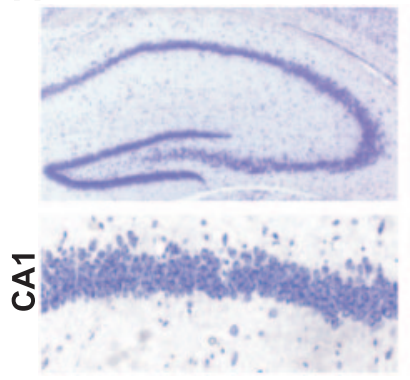

B

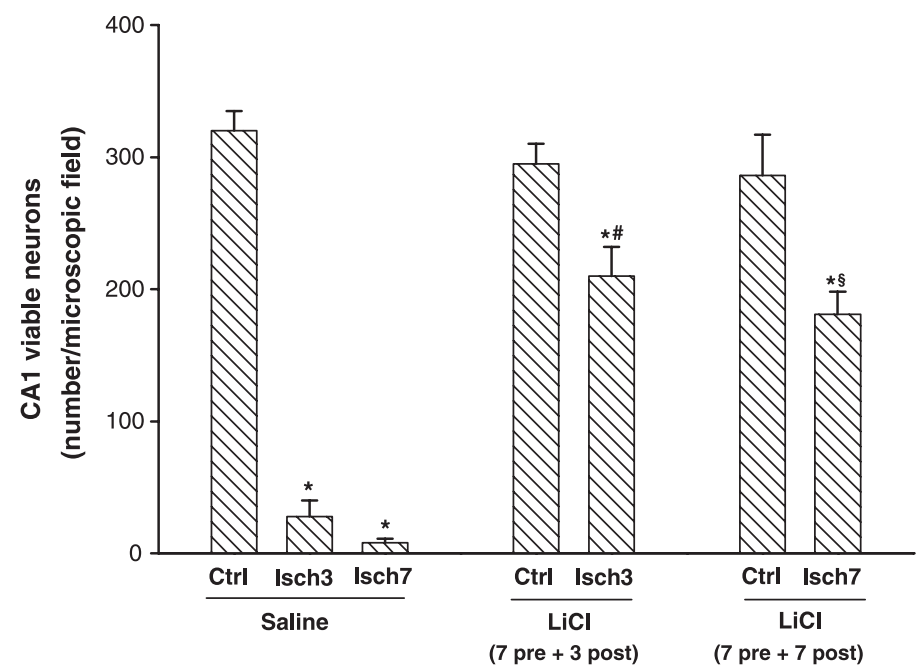

Figure 2. A, Nissl staining of the hippocampus of representative gerbils subjected to $5 \mathrm{~min}$ of ischemia and treated with eithe saline or LiCl (1 mEq/kg every $12 \mathrm{~h}$ for the $7 \mathrm{~d}$ preceding the onset of ischemia and for the next $7 \mathrm{~d})$. CA1 neurons at higher magnification are shown below. Neuronal counts are shown in $\boldsymbol{B}$. Counts refer to $\mathrm{CA1}$ neurons of control (Ctrl) or ischemic gerbils treated with LiCl for $7 \mathrm{~d}$ before and $3 \mathrm{~d}$ after ischemia (damage assessed at $3 \mathrm{~d}$ ) or for $7 \mathrm{~d}$ before and $7 \mathrm{~d}$ after ischemia (damage assessed at $7 \mathrm{~d}$ ). Note that neuroprotection by lithium is maintained at $7 \mathrm{~d}$. Values are means $\pm \mathrm{SEM}$ of determinations from four to six individual gerbils. $p<0.05$; one-way ANOVA plus Fisher's PLSD versus the respective control values $\left({ }^{*}\right)$ versus $3 \mathrm{~d}$ after ischemia (Isch3) in saline-treated gerbils (\#) or versus $7 \mathrm{~d}$ after ischemia (Isch7) in saline-treated gerbils (§).

Dkk-1 sense 5' -TCtGGTCCAAGATCtGtA-3' (Invitrogen, Milan, Italy). Animals were killed $3 \mathrm{~d}$ after the induction of ischemia. Independent groups of animals were used for histological/immunohistochemical analysis and for Western blot analysis.

Rat global ischemia. Age-matched, adult male Sprague Dawley rats (Charles River Laboratories, Wilmington, MA), weighing 100-125 g, were maintained in a temperature- and light-controlled environment with a 14/10 h light/dark cycle and were treated in accordance with the principles and procedures of the National Institutes of Health Guidelines for the Care and Use of Laboratory Animals. Rats were fasted overnight and, on the day of surgery, were subjected to sham operation (control animals) or global ischemia (10 $\mathrm{min}$ ) by four-vessel occlusion, according to the study by Pulsinelli and Brierley (1979). Briefly, animals were anesthetized with halothane (induction, $2 \%$; maintenance, $0.5-1 \%$ ). The vertebral arteries were subjected to electrocauterization; common carotid arteries were exposed and isolated with a 3-0 silk tread, and the wound was sutured. After $24 \mathrm{hr}$, the wound was reopened and carotid arteries were occluded (10 $\mathrm{min})$, followed by reperfusion. Arteries were visually inspected to ensure adequate reflow and then anesthesia was discontinued. For sham operation, animals were subjected to the same anesthesia and surgical procedures, except that carotid arteries were not occluded. Body temperature was maintained at $37^{\circ} \mathrm{C}$ (with a rectal thermistor and heat lamp during and after the induction of global ischemia). Animals were killed at $6,12,24,48$, and $72 \mathrm{~h}$ from the time of occlusion. One group of animals received intraperitoneal injections of lithium chloride $(1 \mathrm{mEq} / \mathrm{kg}$ every $12 \mathrm{~h}$ ) for $7 \mathrm{~d}$ before the induction of ischemia and then for the next $3 \mathrm{~d}$. Different groups of animals were used for histological/ immunohistochemical analysis and biochemical analysis. Hippocampal subfields [CA1 region and dentate gyrus (DG)] were microdissected, and protein and total RNA extracts were processed for Western blot analysis and PCR, respectively.

Immunohistochemistry. Dissected brains were fixed in Carnoi, embedded in paraffin, and sectioned at $10 \mu \mathrm{m}$. Deparaffinized sections were soaked in 3\% hydrogen peroxide to block endogenous peroxidase activity. Sections were incubated overnight with monoclonal mouse antibody anti-p53 $(0.5 \mu \mathrm{g} / \mathrm{ml}$; Ventana Medical Systems, Tucson, AZ) or goat polyclonal antiDkk-1 (1:50; Santa Cruz Biotechnology, Santa Cruz, CA) and then for $1 \mathrm{~h}$ with secondary biotinylated anti-mouse or anti-goat antibodies (1: 200; Vector Laboratories, Burlingame, CA), respectively. For p53, before immunostaining, the sections were placed in MS Unmasker buffer (1:10; Ventana Medical Systems) and heated in a microwave at $750 \mathrm{~W}$ until boiling and then at $350 \mathrm{~W}$ for $30 \mathrm{~min}$. 3,3'Diaminobenzidine tetrachloride was used for detection (ABC Elite kit; Vector Laboratories). Control staining was performed without the primary antibodies.

Histology and quantitative analysis. Dissected brains were processed as described above. Sections $(10 \mu \mathrm{m})$ were processed for staining with thionin (Nissl staining). To assess hippocampal injury, the number of surviving neurons in the pyramidal layer of the medial CA1 region was counted under a light microscope at $20 \times$ magnification. Neurons with a rounded shape similar to that commonly observed in sections from control animals were considered to be viable.

Reverse transcriptase-PCR analysis. Total RNA extracted from the hippocampal CA1 region of rats subjected to transient global ischemia (four-vessel occlusion model), at 24 and $48 \mathrm{~h}$ from the time of occlusion, was subjected to DNaseI treatment (Boehringer Mannheim, Mannheim, Germany) according to the instructions of the manufacturer. Total RNA/sample ( $1 \mu \mathrm{g})$ was then used for cDNA synthesis using SuperScriptII (Invitrogen) and an oligo-dT primer according to the instructions of the manufacturer. Each reverse transcriptase (RT) product was diluted to $100 \mu \mathrm{l}$ with sterile water, and $1 \mu \mathrm{l}$ of cDNA was used in each subsequent amplification. Amplification of Dkk-1 was performed using the following primers for rat Dkk-1: forward, $5^{\prime}$-AATCTGCCTGGCTTGCCGAA-3'; reverse, 5'-GTGGAGCCTGGAAGAATTGC-3'. $\beta$-Actin cDNA amplification was performed by using a pair of primers (Roelen et al., 1994), which span an intron and yield products of different sizes depending on whether CDNA or genomic DNA is used as a template (400 bp for a cDNA-derived product and $600 \mathrm{bp}$ for a genomic DNAderived amplification). PCR products were separated by electrophoresis on a $1 \%$ agarose gel poured and run in $1 \times$ Tris-acetate-EDTA buffer and visualized under UV light.

Western blot analysis. Western blot analysis of Dkk-1 expression was performed in protein extracts of mixed cortical cultures and in protein lysates obtained from the entire hippocampus of gerbils or rats subjected to transient global ischemia, as reported previously (Copani et al., 2002). Dkk-1 protein $(35 \mathrm{kDa})$ was detected with a goat polyclonal antibody $(2$ $\mu \mathrm{g} / \mathrm{ml}$; \#SC-14949; Abcam, Milan, Italy). Phosphorylated and total $\beta$-catenin levels and GSK- $3 \beta$ phosphorylated at Ser9 [P-GSK-3 $\beta$ (Ser9)] levels were examined in rats subjected to global ischemia. Total $\beta$-catenin, P-GSK-3 $\beta$ (Ser9), and LRP5/LRP6 levels were also examined in mixed cortical cultures. Where indicated, nuclear and cytosolic fractions were isolated by differential centrifugation using a commercially available kit (Pierce, Rockford, IL) (Calderone et al., 2003). The purity of 
the fractions was verified with an antibody against the nuclear protein poly(ADP-ribose) polymerase (H-250; Santa Cruz Biotechnology). The following antibodies were used: mouse $\beta$-catenin (1:1000; \#A6290; BD Transduction Laboratories, Beverly, MA), rabbit phospho$\beta$-catenin (Thr41/Ser45) (1:1000; \#9565; Cell Signaling Technology, Lexington, KY), rabbit P-GSK-3 $\beta$ (Ser9) (1:1000; \#9336; Cell Signaling Technology), and mouse LRP5/LRP6 (1:1000; \#3801-100; Biovision, Mountain View, CA). Immunoreactive bands were revealed by ECL (Amersham Biosciences, Milan, Italy).

\section{Results}

Induction of Dkk-1 in the gerbil model of global ischemia

We examined the correlation between neuronal damage and Dkk-1 expression in hippocampal subfields of gerbils subjected to transient global ischemia. A 5 min bilateral carotid occlusion led to a selective degeneration of the CA1 and CA2 regions, as shown by Nissl staining. Neuronal death in the CA1 region was detectable $3 \mathrm{~d}$ after ischemia and became substantial at $7 \mathrm{~d}$, when neurons of the $\mathrm{CA} 2$ region were also damaged. Neurons of the $\mathrm{CA} 3$ region and $\mathrm{DG}$ were spared (Fig. $1 A)$. Immunohistochemical analysis in adjacent sections showed an early expression of Dkk-1 in CA1 neurons, which was already detectable after $6 \mathrm{~h}$ of reperfusion, peaked at $24 \mathrm{~h}$, and started to decline at $3 \mathrm{~d}$ (Fig. $1 A$ ). No expression of Dkk-1 was detectable in the CA3 region (Fig. $1 A$ ) and DG (data not shown) after 5 min of ischemia. An increased expression of Dkk-1 was also observed in non-neuronal cells and blood vessels of the CA1 and CA3 regions from ischemic animals (Fig. $1 A$ ), which may represent an early reaction of glial cells and endothelial cells to ischemia. Western blot analysis performed in the entire hippocampus of separate groups of ischemic gerbils showed an increased expression of Dkk- 1 at $6 \mathrm{~h}, 24 \mathrm{~h}$, and $3 \mathrm{~d}$, which was no longer detectable at $7 \mathrm{~d}$ after ischemia (Fig. $1 B$ ). To examine whether a drug that could rescue the Wnt pathway acting downstream of the Dkk-1 block could be protective against ischemic damage, we treated gerbils with lithium ions, which are known to inhibit GSK-3 $\beta$ (for review, see Bhat et al., 2004). Gerbils subjected to a $5 \mathrm{~min}$ ischemia were injected with $\mathrm{LiCl}$ $(1 \mathrm{mEq} / \mathrm{kg}$, i.p.) every $12 \mathrm{~h}$ for $7 \mathrm{~d}$ before the onset of ischemia and then for the next 3 or $7 \mathrm{~d}$. Lithium treatment protected CA1 neurons against ischemic death. Protection was substantial, albeit partial, when neuronal damage was assessed $3 \mathrm{~d}$ after ischemia, and was maintained in animals killed $7 \mathrm{~d}$ after ischemia (Fig. $2 A, B$ ). We also examined the action of lithium in gerbils subjected to $6 \mathrm{~min}$ of ischemia. In these animals, CA1 neurons were extensively damaged after $3 \mathrm{~d}$, when a small damage of CA3 neurons was also observed (Fig. $3 A$ ). Dkk-1 expression was increased in CA1 neurons at 6-72 h after ischemia (Figs. 3C, 4) and also in CA3 neurons at $72 \mathrm{~h}$ after ischemia (data not shown). Repeated injections of $\mathrm{LiCl}(1 \mathrm{mEq} / \mathrm{kg}$, i.p.; every $12 \mathrm{~h}$ for $7 \mathrm{~d}$ before the onset of ischemia and then for the next $3 \mathrm{~d}$ ) delayed the development of neuronal death in the CA1 and CA3 regions of ischemic gerbils without reducing the expression of Dkk-1 (Fig. 3A-C). Neuroprotection was lost in gerbils killed $4 \mathrm{~d}$ after the end of lithium treatment (i.e., $7 \mathrm{~d}$ after the $6 \mathrm{~min}$ ischemia) when, however, the selective vulnerability typical of this model was lost and a severe neuronal damage was observed across all hippocampal subfields (data not shown). We used gerbils subjected to severe ischemia (i.e., 6 min of ischemia), and the animals were killed after $3 \mathrm{~d}$ to examine the direct relationship between Dkk-1 expression and neuronal death. Animals were treated with a Dkk-1 antisense oligonucleotide corresponding to highly conserved DNA sequence present in the rat, mouse, and human Dkk-1 gene. The corresponding Dkk-1 sense oligonucleotide was used as a control. Both Dkk-1 antisense and sense oligonucleotides $(12 \mu \mathrm{M} / 2 \mu \mathrm{l})$ were injected intracerebroventricularly 24 and $1 \mathrm{~h}$ before the onset of ischemia and then once per day for the next $3 \mathrm{~d}$. Antisense treatment was associated with a full protection of CA1 neurons against ischemic damage (assessed at $3 \mathrm{~d}$ ), an effect that was associated with the lack of Dkk-1 expression (Fig. 4A,B). We extended the immunohistochemical analysis to the tumor-suppressing protein, p53, the levels of which are known to increase during the development of ischemic neuronal damage (McGahan et al., 1998; Tomasevic et al., 1999). A clear-cut increase in the expression of $\mathrm{p} 53$ was detected in degenerating neurons of ischemic gerbils treated with saline or with the Dkk-1 sense oligonucleotide. Interestingly, p53 expression was also increased (albeit to a lesser extent) in neurons rescued by the antisense treatment at $3 \mathrm{~d}$ after ischemia (Fig. 4), suggesting that Dkk-1 induction is a necessary requirement for the execution of a death program in neurons expressing $\mathrm{p} 53$.

\section{Induction of Dkk-1 in rats subjected to global ischemia by four-vessel occlusion}

In rats subjected to $10 \mathrm{~min}$ of global ischemia, there was no histologically detectable neuronal death in any hippocampal subfield at $2 \mathrm{~d}$, whereas a selective neuronal loss was observed in CA1 
A

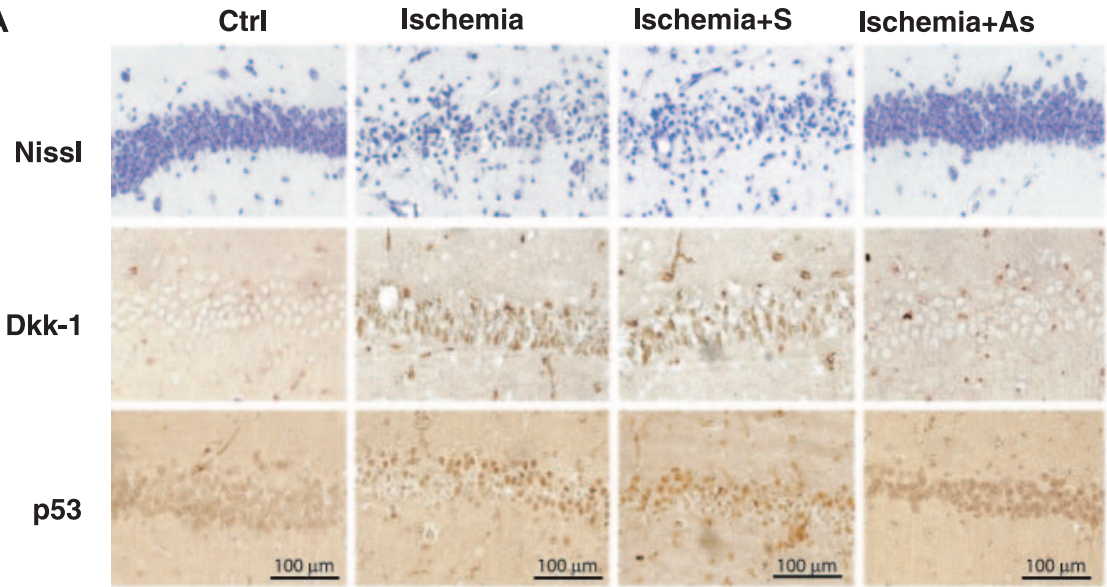

B

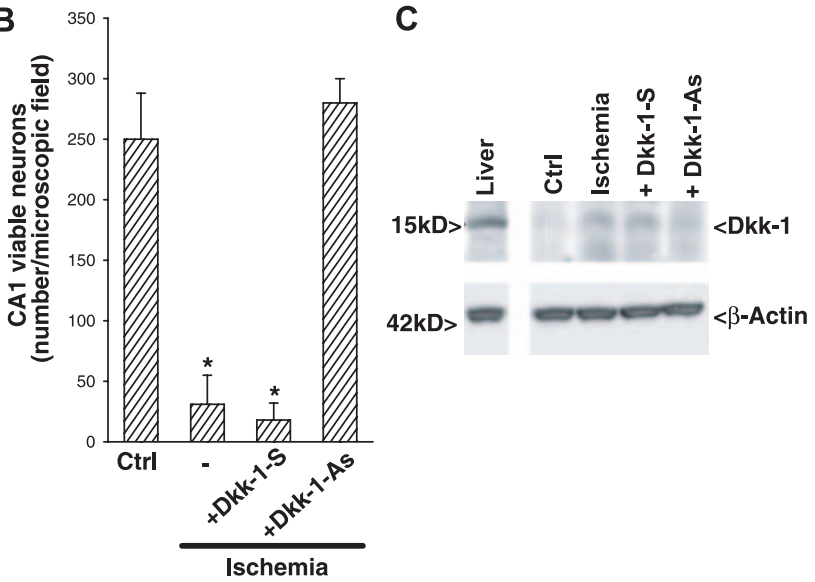

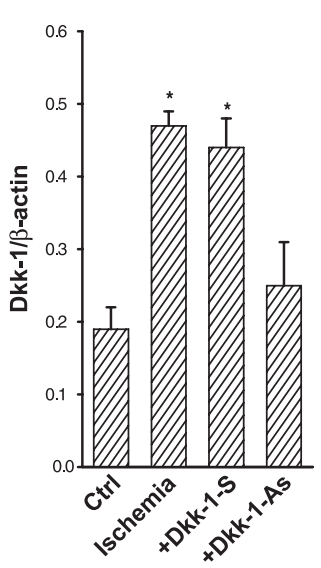

Figure 4. A, Nissl staining, Dkk-1 immunostaining, and p53 immunostaining in the CA1 region of control (Ctrl) gerbils and ischemic gerbils treated intracerebroventricularly with saline (indicated as ischemia alone), Dkk-1 antisense oligonucleotides (Dkk-1-As), or Dkk-1 sense oligonucleotides (Dkk-1-S) (both injected at a dose of $12 \mathrm{nmol} / 2 \mu \mathrm{l}, 24$ and $1 \mathrm{~h}$ before ischemia, and then once daily for the next $3 \mathrm{~d}$ ). Animals were subjected to $6 \mathrm{~min}$ of ischemia and killed $3 \mathrm{~d}$ later. Neuronal counts: one-way ANOVA plus Fisher's PLSD versus controls. Note in Figure $2 A$ that $p 53$ expression was increased in CA1 neurons of gerbils treated with Dkk-1-As. Identical results were obtained in all gerbils examined ( $n=6$ per group). Western blot analysis of Dkk-1 in separate groups of gerbils treated with Dkk-1-As and Dkk-1-S is shown in C. Values are means \pm SEM of four to five determinations. * $p<0.05$; one-way ANOVA plus Fisher's PLSD versus control gerbils.

neurons at $7 \mathrm{~d}$ after reperfusion; CA3 and DG neurons showed no damage (data not shown) (Calderone et al., 2003; Tanaka et al., 2004). Immunohistochemical analysis in sham-operated rats showed a low constitutive expression of Dkk-1 (particularly in the CA1 region), which was absent in control gerbils (compare the control immunostaining in the CA1 region in Figs. 1 and $5 A$ ). A substantial increase in Dkk-1 immunoreactivity was detected in CA1 neurons at $24 \mathrm{~h}$ after ischemia. Dkk-1 expression also increased in CA3 neurons, albeit to a lesser extent. No Dkk-1 immunostaining was detected at $3 \mathrm{~d}$, perhaps because of the extensive neuronal loss in the CA1 region (Fig. 5A). No increase in Dkk-1 expression was seen in non-neuronal cells in the rat model of global ischemia. Western blot analysis showed an increased expression of Dkk-1 in microdissected CA1 region at 24 and $48 \mathrm{~h}$ after ischemia (i.e., at times that preceded neuronal death) (Fig. $5 B$ ); no increase in Dkk-1 expression was detected in the DG at any time (Fig. 5C). Using the four-vessel occlusion model, we could also measure the expression of Dkk-1 mRNA, because the rat Dkk-1 gene sequence is available. RT-PCR analysis showed an increased expression of Dkk-1 mRNA at both 24 and $48 \mathrm{~h}$ after ischemia (Fig. 5D). We extended the analysis to the levels of $\beta$-catenin, a protein that lies downstream within the canonical

Wnt signaling pathway. A Wnt-mediated inhibition of GSK-3 $\beta$ enhances the stabilization of $\beta$-catenin, which translocates to the nucleus and regulates gene expression (Hinck et al., 1994; Aberle et al., 1997; Willert and Nusse, 1998). Thus, nuclear levels of $\beta$-catenin are reliable indicators of the activity of the Wnt pathway. Nuclear $\beta$-catenin levels were markedly reduced in the CA1 region at 12,24 , and $48 \mathrm{~h}$ after ischemia (Fig. 6A). This was associated with a relative increase in the nuclear levels of phosphorylated $\beta$-catenin (on Thr41 and Ser45) (Fig. 6B). No changes in total (Fig. $6 C$ ) or phosphorylated (data not shown) $\beta$-catenin levels were found in the cytoplasmic fraction prepared from the CA1 region of ischemic gerbils. Assessment of the Ser9 phosphorylated, inhibited form of GSK- $3 \beta$ showed an early and transient reduction at $12 \mathrm{~h}$ after ischemia in the nuclear fraction (Fig. $6 E$ ). Levels of Ser9 phosphorylated GSK-3 $\beta$ were also transiently reduced in the cytoplasmic fraction but at a later time $(24 \mathrm{~h})$ after ischemia (Fig. 6D). No changes in the total levels of GSK- $3 \beta$ were observed up to $24 \mathrm{~h}$ after ischemia, whereas 22 and $34 \%$ reductions were seen in the cytoplasmic and nuclear fractions at $48 \mathrm{~h}$ after ischemia (data not shown). Using the same experimental protocol adopted in ischemic gerbils, we treated rats with $\mathrm{LiCl}(1 \mathrm{mEq} / \mathrm{kg}$, i.p.) every $12 \mathrm{~h}$ for $7 \mathrm{~d}$ before ischemia and then for the next $3 \mathrm{~d}$. This treatment partially protected CA1 neurons against ischemic death (Fig. $7 A, B$ ).

\section{Induction of Dkk-1 is associated with excitotoxic neuronal death in culture} We used mixed cultures of mouse cortical cells in which neurons were plated over a monolayer of confluent astrocytes. These cultures are widely used for studies of excitotoxic neuronal death, because they offer the advantage of preserving the physiological interplay between neurons and astrocytes. We have shown previously that cortical neurons in culture express the mRNA for various members of the Wnt glycoprotein family and for the Wnt coreceptors Frizzled-1 to Frizzled-9 and LRP5 and LRP6 (Caricasole et al., 2004). Mixed cultures of cortical cells expressed high levels of the Wnt/Dkk-1 membrane coreceptor, LRP5/LRP6, as detected by Western blot analysis (Fig. $8 A$ ). Expression was much lower in extracts from pure cultures of mouse astrocytes (Fig. $8 \mathrm{~A}$ ), suggesting that neurons are the main source of LRP5/LRP6 in mixed cultures. Cultures were exposed to a $10 \mathrm{~min}$ pulse with NMDA at concentrations that induce $\sim 50-60$ and $30 \%$ of neuronal death $(60$ and $30 \mu \mathrm{M}$, respectively). In typical experiments, neuronal death becomes detectable $\sim 12 \mathrm{~h}$ after the toxic pulse, as assessed by trypan blue staining and LDH release. Western blot analysis showed an increased production of Dkk-1 at both 6 and $24 \mathrm{~h}$ after the NMDA pulse (Fig. $8 \mathrm{~B}$ ). Cultures were treated with a Dkk-1 antisense oligonucleotide designed on mouse Dkk-1 cDNA ( $1.5 \mu \mathrm{M}$; preincubated for $16 \mathrm{~h}$ before the excitotoxic pulse and maintained for the next 
$24 \mathrm{~h})$ to examine the causal relationship between Dkk-1 induction and neuronal death. Antisense treatment attenuated neuronal death induced by 30 or $60 \mu \mathrm{M}$ NMDA (Fig. 8C) and lowered the expression of Dkk-1 in NMDA-treated cultures (Fig. $8 B$ ). The respective Dkk-1 sense oligonucleotide ( $1.5 \mu \mathrm{M}$; applied similarly to the Dkk-1 antisense) did not produce any of these effects (Fig. 8B,C). Treatment with $10 \mathrm{~mm} \mathrm{LiCl}$ (added to the cultures immediately after the NMDA pulse) also reduced NMDA toxicity (Fig. $8 C$ ). We also assessed the expression of $\beta$-catenin and P-GSK-3 $\beta$ (Ser9) in mixed cultures at $8 \mathrm{~h}$ after the NMDA pulse. NMDA induced a substantial reduction in the total levels of $\beta$-catenin in the nuclear and cytoplasmic fraction, whereas a significant reduction in P-GSK-3 $\beta$ (Ser9) was only detected in the nuclear fraction (Fig. 8D,E). We could not detect levels of phosphorylated $\beta$-catenin in mixed cortical cultures. Total $\beta$-catenin levels were also assessed in the cytoplasmic fraction of cultures challenged with NMDA and treated with the Dkk-1 antisense oligonucleotides or with $\mathrm{LiCl}$, as described above. Both treatments attenuated the reduction of total $\beta$-catenin levels induced by the NMDA pulse, whereas the Dkk-1 sense oligonucleotide had no effect (Fig. 8D). In contrast, Dkk-1 antisense treatment did not affect the reduction in nuclear P-GSK-3 $\beta$ (Ser9) levels observed in cultures challenged with NMDA (Fig. $8 E$ ). Finally, cultures were treated with two concentrations of recombinant human Dkk-1 (10 or $100 \mathrm{ng} / \mathrm{ml}$ ) applied either during or immediately after the NMDA pulse. Dkk-1 alone induced only a small increase in neuronal death, which was completely prevented in cultures treated with $\mathrm{LiCl}$. When combined with NMDA, Dkk-1 potentiated NMDA toxicity in a concentration-dependent manner when applied either during the pulse (for only $10 \mathrm{~min}$ ) or immediately after the pulse (and maintained for the next $24 \mathrm{~h}$ ) (Fig. 9A,B). Treatment with $10 \mathrm{~mm} \mathrm{LiCl}$ significantly reduced the toxicity induced by NMDA alone or NMDA plus Dkk-1, although Dkk-1 could still enhance NMDA toxicity in the presence of lithium ions (Fig. 9A,B).

\section{Discussion}

Negative modulators of the Wnt pathway can be divided into two classes: (1) the secreted Frizzled-related proteins (sFRPs), which bind directly to Wnt and include sFRP1 to sFRP5, Wnt inhibitory factor-1, and Cerberus; and (2) the Dkk proteins, which bind to the Wnt coreceptors, LRP5/LRP6, and include Dkk-1 to Dkk-4, and the Dkk-3-related protein Soggy (for review, see Kawano and Kypta, 2003). Dkk-1 and Dkk-4 at

A

Niss!

B

C

D
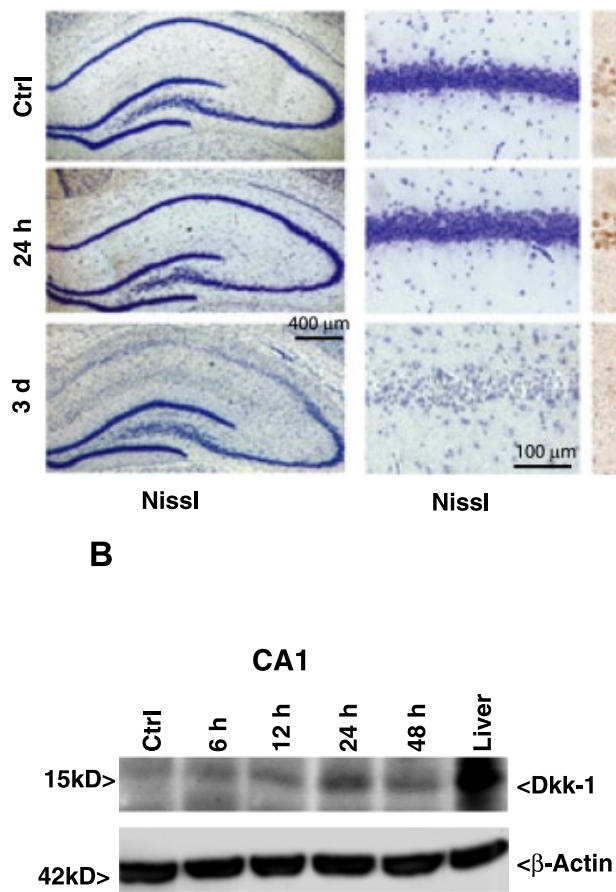

Niss!

CA1

CA3

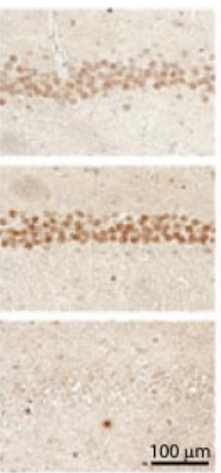

Dkk-1

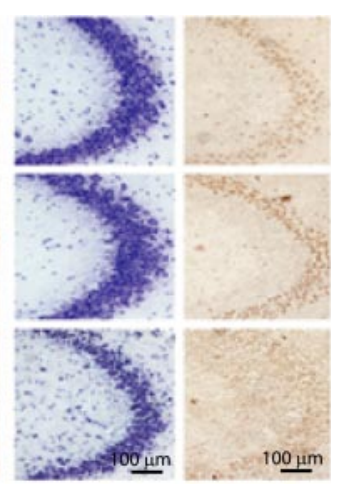

Niss!

Dkk-1
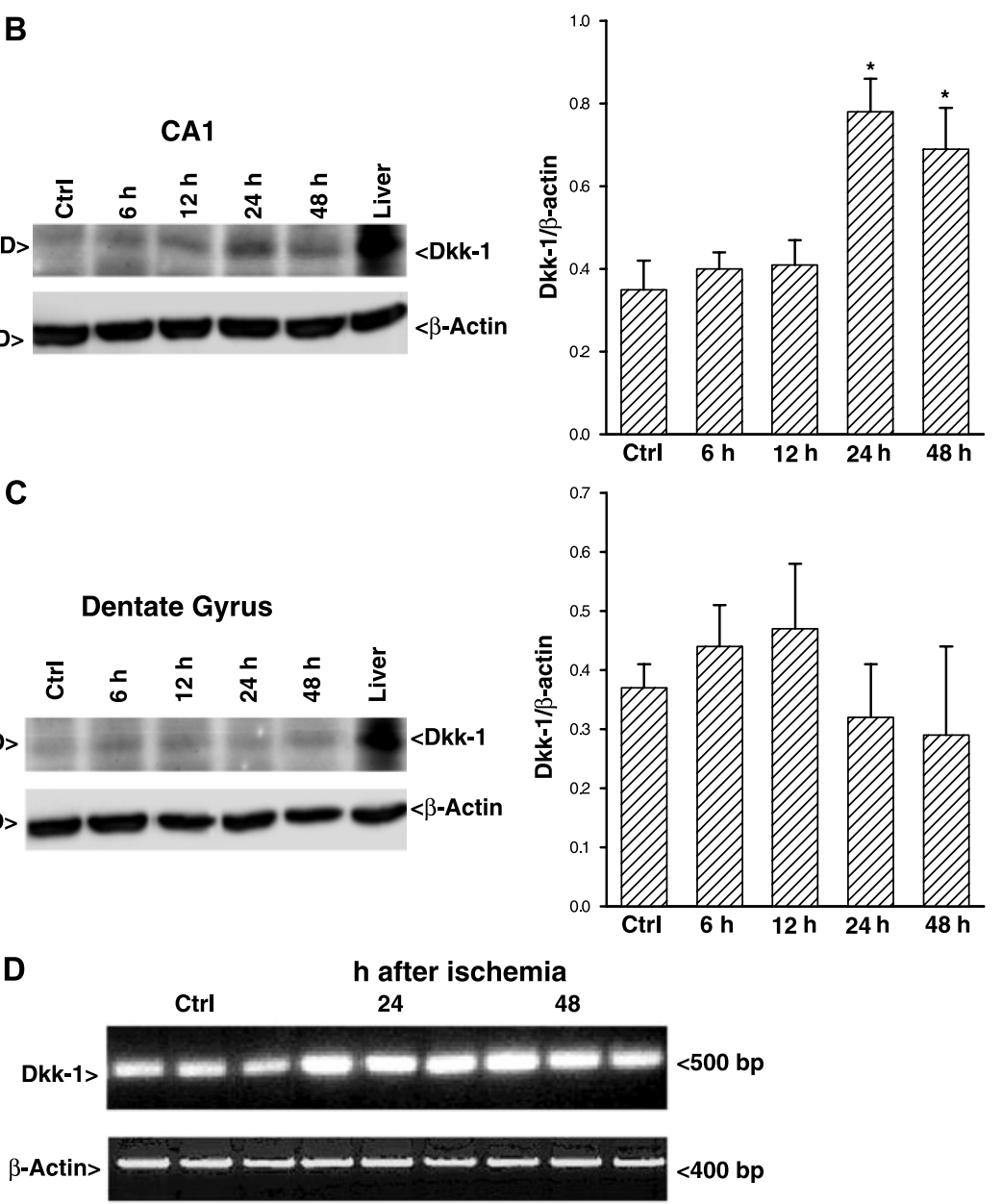

Figure 5. A, Temporal profile of Dkk-1 expression in the hippocampus of rats subjected to global ischemia by four-vessel occlusion. Nissl staining and Dkk-1 immunostaining in adjacent sections of the CA1 and CA3 regions of a representative animal at different times after ischemia are shown. $\boldsymbol{A}$, Nissl staining of the entire hippocampus is also shown. An identical Dkk-1 expression profile was found in all animals examined $(n=6)$. The time-dependent expression of Dkk-1 protein in the CA1 region and DG of rats subjected to global ischemia by four-vessel occlusion is shown in $\boldsymbol{B}$ and $\boldsymbol{C}$, respectively. Ctrl, Control. Values are means \pm SEM of four determinations. * $p<0.05$; one-way ANOVA plus Fisher's PLSD versus controls (sham-operated rats). RT-PCR analysis of Dkk-1 mRNA in the CA1 region of control and ischemic rats $(n=3)$ is shown in $\boldsymbol{D}$. Samples were not contaminated by genomic DNA, as indicated by the presence of a single $400 \mathrm{bp} \beta$-actin amplimer (see Materials and Methods).

least inhibit the canonical Wnt/Frizzled/GSK-3 $\beta / \beta$-catenin pathway by forming a ternary complex with LRP6 and Kremen $1 / 2$ membrane receptors, thus promoting the endocytosis of the Wnt coreceptor, LRP6 (Mao et al., 2002). A role for Dkk-1 has been extensively studied during early development, when Dkk-1 has a head-inducing activity (Glinka et al., 1998; Mukhopadhyay 


\section{A}

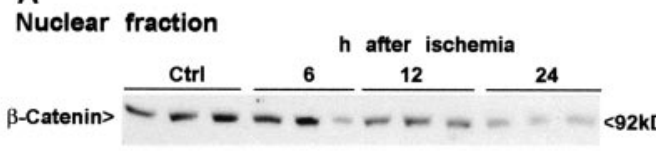

B

Nuclear fraction

$<92 \mathrm{kD}$

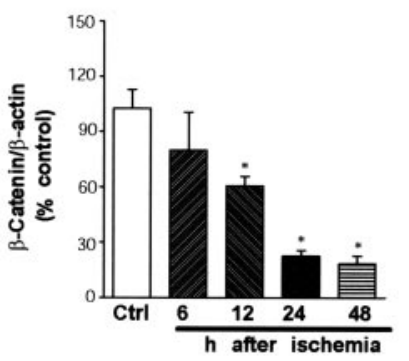

C

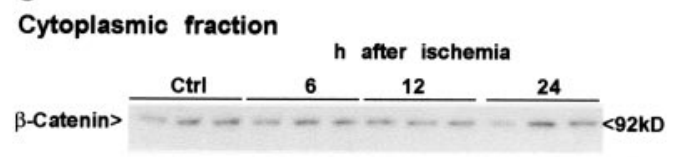

D

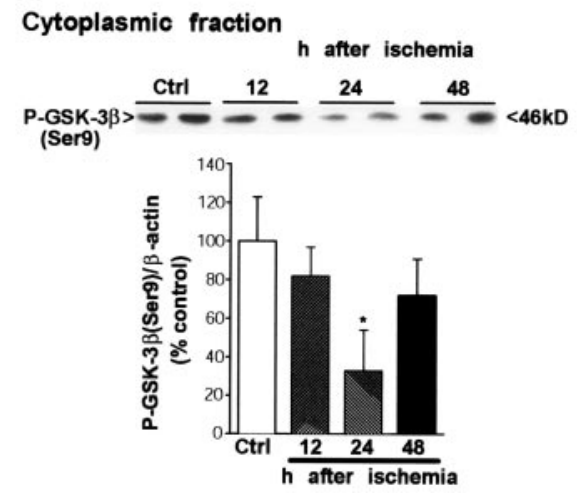

E

Nuclear fraction
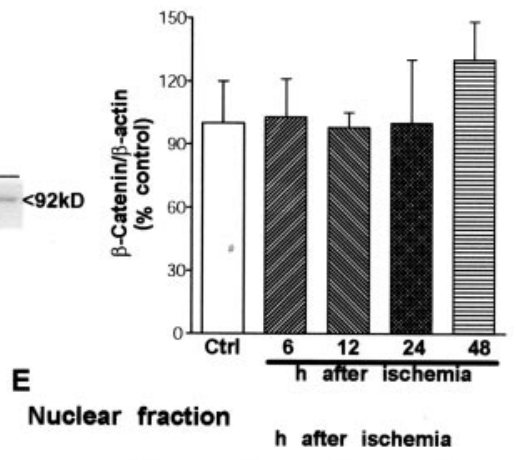

P-GSK-3
(Ser9)
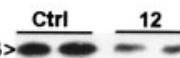

ischemia

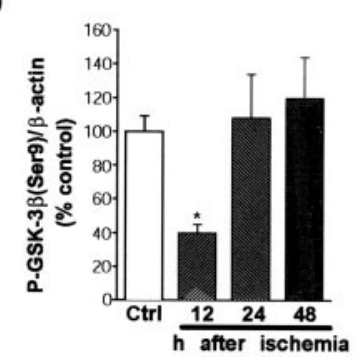

Figure 6. Total $(\boldsymbol{A})$ and phosphorylated $(\boldsymbol{B}) \beta$-catenin levels in the nuclear fraction and total $\beta$-catenin levels in the cytoplasmic fraction ( $C$ prepared from the $C A 1$ region of rats subjected to global ischemia. The anti-phospho- $\beta$-catenin antibody we used recognizes phosphorylated epitopes at Thr 41 and Ser 45 of $\beta$-catenin. Values are means \pm SEM of four to six determinations. ${ }^{*} p<0.05$; one-way ANOVA plus Fisher's PLSD versus control values. Levels of Ser9 phosphorylated GSK- $3 \beta$ in the cytoplasmic and nuclear fractions prepared from the $C A 1$ region of rats subjected to global ischemia are shown in $\boldsymbol{D}$ and $\boldsymbol{E}$, respectively. Values are means \pm SEM of four to six determinations. ${ }^{*} p<0.05$; one-way ANOVA plus Fisher's PLSD versus control values. Ctrl, Control.

et al., 2001). We recently showed that Dkk-1 is induced in differentiated neurons challenged with $\beta$-amyloid peptide and is found in degenerating neurons of the Alzheimer's brain (Caricasole et al., 2004). Inhibition of the Wnt pathway by Dkk-1 contributes to the execution of the death program and to hyperphosphorylation of the tau protein in $\beta$-amyloid-treated neurons (Caricasole et al., 2004). Here, we extended the study to ischemic and excitotoxic neuronal damage, where a causal role for Dkk-1 was suggested by the following observations: (1) a clear induction of Dkk-1 was found both in cultured cortical cells challenged with NMDA and in hippocampal neurons of gerbils or rats subjected to transient global ischemia; (2) the temporal and regional profile of Dkk-1 expression correlated with the selective pattern of neuronal vulnerability in ischemic animals; and (3) the antisense-induced knockdown of Dkk-1 showed a substantial neuroprotective activity in both in vitro and in vivo models. Neuroprotection was also observed with lithium ions, which mimic the activation of the Wnt pathway by inhibiting GSK-3 $\beta$.

The study of global ischemia in gerbils offered the advantage of an accurate assessment of the regional profile of neuronal damage. Using the conventional $5 \mathrm{~min}$ occlusion paradigm, we detected a selective death of CA1 pyramidal neurons, which became substantial at $3 \mathrm{~d}$ after reperfusion. Remarkably, Dkk-1 was expressed selectively in CA1 neurons at times preceding neuronal death $(6$ and $24 \mathrm{~h}$ after ischemia). A correlation between Dkk-1 expression and ischemic death was strengthened by experiments in which we prolonged the occlusion time to $6 \mathrm{~min}$. Under these conditions, neuronal damage was extended to the CA3 region and, ultimately, also to the DG. In these animals, Dkk-1 was first expressed in CA1 neurons and then to CA3 neurons, always at times that preceded neuronal death. A similar scenario was observed in rats subjected to four-vessel occlusion, in which neuronal death occurs selectively in CA1 neurons and becomes detectable $>48 \mathrm{~h}$ after reperfusion (Calderone et al., 2003; Tanaka et al., 2004). In these animals, an early expression of Dkk-1 (6-48 h after ischemia) was selectively found in the CA1 region. Treatment with Dkk-1 antisense oligonucleotides was highly efficient in protecting $\mathrm{CA} 1$ and $\mathrm{CA} 3$ neurons in gerbils subjected to a 6 min ischemia, a condition that induced a substantial neuronal death in the hippocampus. Although it can be argued that oligonucleotides might be protective via nonspecific mechanisms and that Dkk-1 expression was not detected because neurons were not committed to death, this seems unlikely because Dkk-1 sense oligonucleotides were inactive. Neuroprotection by Dkk-1 antisenses was also found in mixed cultures of mouse cortical cells exposed to a transient toxic pulse with NMDA, reinforcing the hypothesis that induction of Dkk-1 contributes to neuronal death.

The Dkk-1 gene is targeted by the tumor-suppressing protein, p53 (Wang et al., 2000), and induction of Dkk-1 is suppressed by p53 knock-down in neurons challenged with $\beta$-amyloid (Caricasole et al., 2004). An increased expression of p53 was still detected in CA1 neurons of ischemic gerbils treated with Dkk-1 antisenses, despite a full neuronal rescue (at least $3 \mathrm{~d}$ after ischemia). This suggests that induction of Dkk-1 is downstream of p53 and is a necessary requirement for the execution of the death program. This was a surprising finding, because Dkk-1 is not classically included in the list of p53-target proteins, which mediate the execution of cell death (for review, see Hofseth et al., 2004; Slee et al., 2004). That idea that Dkk-1 can promote cell death is supported by the findings that its overexpression sensitizes brain tumor cells to apoptosis after alkylation damage of DNA (Shou et al., 2002). A possible scenario occurring in ischemic neurons is 
that the induction phase of the damage leads to a massive influx of extracellular calcium and DNA damage, with a sequential induction of p53 and Dkk-1. Inhibition of the Wnt pathway by Dkk-1 might synergize with the classical proapoptotic program triggered by $\mathrm{p} 53$, reaching the threshold for neuronal death. One of the consequences of the impairment of Wnt signaling is an increased degradation of $\beta$-catenin resulting from disinhibition of GSK-3 $\beta$ (Kim et al., 2003; Levina et al., 2004). This will deprive suffering neurons from a trophic support provided by the gene program triggered by $\beta$-catenin (Willert and Nusse, 1998). Dkk-1 may relieve the inhibitory constraint of the Wnt pathway on GSK-3 $\beta$ activity, leading to phosphorylation of $\beta$-catenin, which is degraded via the ubiquitin/proteasome complex and is no longer available for nuclear translocation (Aberle et al., 1997; Hart et al., 1998). Alternatively, $\beta$-catenin can be phosphorylated by GSK-3 $\beta$ inside the nucleus (Bijur and Jope, 2003). We found a substantial reduction of nuclear $\beta$-catenin levels associated with a relative increase in phosphorylated $\beta$-catenin in the CA1 region of ischemic rats. Levels of $\beta$-catenin did not change in the CA1 cytoplasmic fraction, perhaps because in that particular tissue, a large pool of cytoplasmic $\beta$-catenin is linked to cadherins and is not regulated by the Wnt pathway. A reduction of both nuclear and cytoplasmic $\beta$-catenin levels was instead detected in mixed cultures of cortical cells challenged with NMDA after 8 h (i.e., $2 \mathrm{~h}$ after the earliest detected increase in Dkk-1 expression). We also found an early reduction in the inhibited Ser9 phosphorylated form of GSK- $3 \beta$ in the CA1 nuclear fraction of ischemic rats. However, nuclear P-GSK-3 $\beta$ (Ser9) levels recovered at later times despite an additional increase in the nuclear levels of phosphorylated $\beta$-catenin, suggesting that phosphorylation of GSK-3 $\beta$ at Ser9 is not under the control of the Wnt pathway and is not critical for the regulation of $\beta$-catenin phosphorylation. This was further supported by the following observations: (1) P-GSK$3 \beta$ (Ser9) levels were reduced in the cytoplasmic fraction from the rat CA1 region at $24 \mathrm{~h}$ after ischemia without any detectable change in cytoplasmic $\beta$-catenin; (2) there were no changes in cytoplasmic P-GSK-3 $\beta$ (Ser9) levels in cultured neurons treated with NMDA despite the reduction in $\beta$-catenin levels; and (3) the NMDA-dependent reduction in nuclear P-GSK-3 $\beta$ (Ser9) was still observed in cultures treated with Dkk-1 antisenses. Thus, our data are consistent with the view that the Wnt pathway inhibits GSK-3 $\beta$ independently of enzyme phosphorylation on Ser9 (Frame et al., 2001).

In addition to promoting $\beta$-catenin degradation, inhibition of the Wnt pathway by Dkk-1 might also enhance the GSK-3 $\beta$ mediated phosphorylation of the tau protein with an ensuing impairment of cytoskeletal dynamics, as shown in neurons challenged with $\beta$-amyloid (Caricasole et al., 2004). Although tau phosphorylation was not examined here, it is noteworthy that changes in tau phosphorylation have been observed during cardiac arrest-induced cerebral ischemia and reperfusion (Mailliot et al., 2000), transient forebrain ischemia in rats (Shackelford and Yeh, 1998), and in cortical slices subjected to hypoxia combined with glucose deprivation (Burkhart et al., 1998).

Our results raise the intriguing possibility that Dkk-1 antagonists or drugs that rescue the Wnt pathway acting downstream of the Dkk-1 blockade are of potential value in the experimental treatment of brain ischemia. Dkk-1 antagonists are not yet available, but their rational design is allowed by the evidence that Dkk-1 and Wnts bind to two distinct recognition sites at the LRP5/LRP6 coreceptors (Zorn, 2001). Drugs acting as inhibitors of GSK-3 $\beta$ may rescue the Wnt pathway despite an increased expression of Dkk-1. Among these, lithium ions are known to protect neurons against excitotoxic and ischemic death (Nonaka et al., 1998; Wei et al., 2001; Xu et al., 2003; Senatorov et al., 2004) and, in ischemic gerbils and rats, lithium treatment was neuroprotective despite the increased expression of Dkk-1 (present data). In cortical cultures, lithium ions abolished the small neuronal toxicity induced by exogenous application of Dkk-1 and attenuated toxicity induced by NMDA alone or by NMDA combined with exogenous Dkk-1. However, exogenous Dkk-1 was still able to potentiate NMDA toxicity in the presence of lithium, suggesting that the combination of NMDA with pharmacological concentrations of Dkk-1 recruits additional neurotoxic pathways that are lithium insensitive. Although protection by lithium might be accounted for by multiple mechanisms (Chen et al., 2003; R. Hashimoto et al., 2002a,b, 2003; Ma et al., 2004), our data support the hypothesis that inhibition of GSK-3 $\beta$ is a promising strategy in the treatment of brain ischemia. Brain-permeant synthetic GSK- $3 \beta$ inhibitors might offer the advantage of rescu- 
A

B

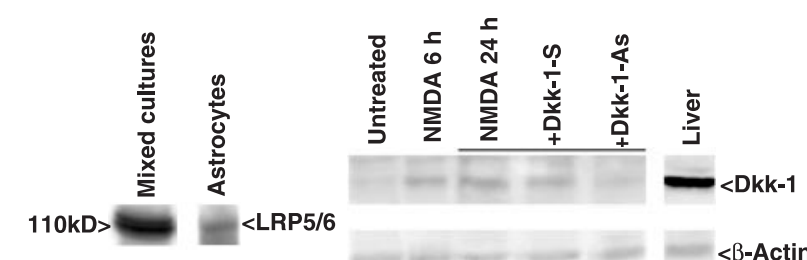

C
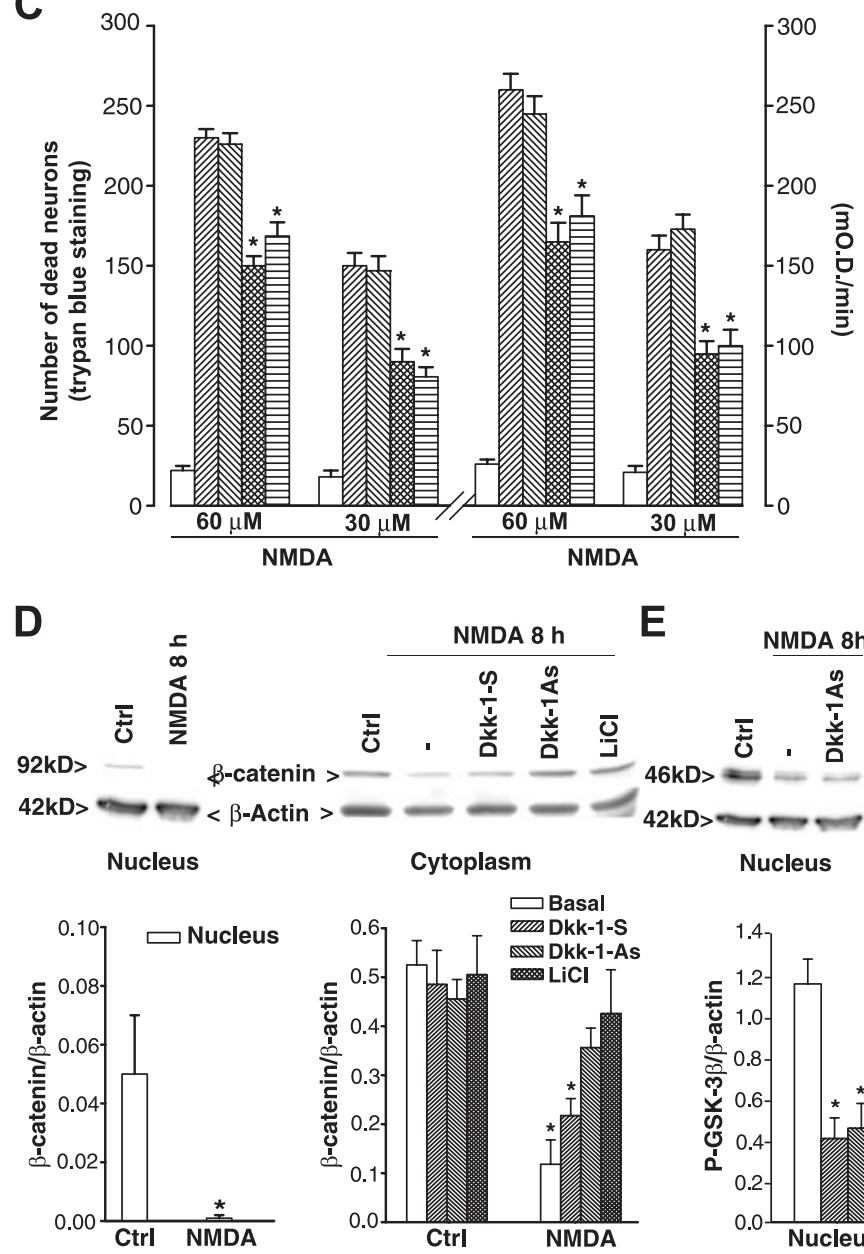

E

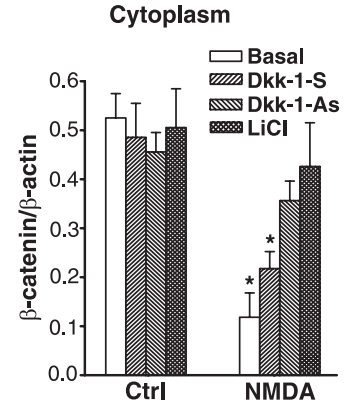

Figure 8. A, Western blot analysis of the Wnt/Dkk-1 membrane coreceptor, LRP6, in mixed mouse cortical cultures and in pure cultures of mouse cortical astrocytes. Induction of Dkk- 1 in mixed cultured cortical cells at 6 and $24 \mathrm{~h}$ after an excitotoxic pulse with $60 \mu \mathrm{m}$ NMDA is shown in B. Expression of Dkk-1 in cultures treated with mouse Dkk-1 antisense (Dkk-1-As) and sense (Dkk-1-S) oligonucleotides is also shown. Values are means \pm SEM of four to eight determinations from two independent experiments. ${ }^{*} p<0.05$ (one-way ANOVA plus Fisher's PLSD) versus control cultures. C, Neuronal degeneration in mixed cortical cultures exposed to a 10 min pulse with 30 or $60 \mu \mathrm{M}$ NMDA and treated with Dkk-1-As or Dkk-1-S (1.5 $\mu \mathrm{M}$, added $16 \mathrm{~h}$ before the NMDA pulse and then immediately after the pulse) or with $\mathrm{LiCl}(10 \mathrm{~mm}$, added immediately after the NMDA pulse). Neuronal death was assessed $24 \mathrm{~h}$ after the NMDA pulse. Values are mean \pm SEM of 12 determinations from three independent experiments and are expressed as the number of dead neurons (from 3 microscopic fields/well) and as LDH released in the culture medium from damaged or dead neurons. ${ }^{*} p<0.05$; one-way ANOVA plus Fisher's PLSD versus NMDA alone. Levels of $\beta$-catenin and P-GSK$3 \beta($ Ser9) in the nuclear and cytoplasmic fractions of mixed cultures exposed to NMDA alone or combined with Dkk-1-As, Dkk-1-S, or $\mathrm{LiCl}$ (added as described above) are shown in $\boldsymbol{D}$ and $\boldsymbol{E}$, respectively. Values are means \pm SEM of six to nine determinations. ${ }^{*} p<$ 0.05; one-way ANOVA plus Fisher's PLSD versus control values. Ctrl, Control.

ing the Wnt pathway without inducing the harmful adverse effects typical of lithium treatment.

\section{References}

Aberle H, Bauer A, Stappert J, Kispert A, Kemler R (1997) $\beta$-Catenin is a target for the ubiquitin-proteasome pathway. EMBO J 16:3797-3804.
Bhat RV, Shanley J, Correl MP, Fieles WE, Keith RA, Scott CW, Lee C (2000) Regulation and localization of tyrosine 216 phosphorylation of glycogen synthase kinase- $3 \beta$ in cellular and animal models of neuronal degeneration. Proc Natl Acad Sci USA 97:11074-11079.

Bhat RV, Budd Haeberlein SL, Avila J (2004) Glycogen synthase kinase 3: a drug target for CNS therapies. J Neurochem 89:1313-1317.

Bijur GN, Jope RS (2003) Glycogen synthase kinase-3 beta is highly activated in nuclei and mitochondria. NeuroReport 14:2415-2419.

Burkhart KK, Beard DC, Lehman RA, Billingsley ML (1998) Alterations in the tau phosphorylation in rat and human neocortical brain slices following hypoxia and glucose deprivation. Exp Neurol 154:464-472.

Calderone A, Jover T, Noh K-M, Tanake H, Yokota H, Lin Y, Grooms SY, Regis R, Bennet MVL, Zukin RS (2003) Ischemic insults derepress the gene silencer REST in neurons destined to die. J Neurosci 23:2112-2121.

Caricasole A, Copani A, Caruso A, Caraci F, Iacovelli L, Sortino MA, Terstappen GC, Nicoletti F (2003) The Wnt pathway, cell-cycle activation and $\beta$-amyloid: novel therapeutic strategies in Alzheimer's disease? Trends Pharmacol Sci 24:233-238.

Caricasole A, Copani A, Caraci F, Aronica E, Rozemuller AJ, Caruso A, Storto M, Gaviraghi G, Terstappen GC, Nicoletti F (2004) Induction of Dickkopf-1, a negative modulator of the Wnt pathway, is associated with neuronal degeneration in Alzheimer's brain. J Neurosci 24:6021-6027.

Chalecka-Franaszek E, Chuang DM (1999) Lithium activates the serine/threonine kinase Akt- 1 and suppresses glutamate-induced inhibition of Akt-1 activity in neurons. Proc Natl Acad Sci USA 96:8745-8750.

Chen G, Bower KA, Ma C, Fang S, Thiele CJ, Luo J (2004) Glycogen synthase kinase $3 \beta$ (GSK3 $\beta$ ) mediates 6-hydroxydopamine-induced neuronal death. FASEB J 18:1162-1164.

Chen RH, Ding WV, McCormick F (2000) Wnt signaling to beta-catenin involves two interactive components: glycogen synthase kinase- $3 \beta$ and activation of protein kinase C. J Biol Chem 275:17894-17899.

Chen RW, Qin ZH, Ren M, Kanai H, ChaleckaFranaszek E, Leeds P, Chuang DM (2003) Regulation of c-Jun N-terminal kinase, p38 kinase and AP-1 DNA binding in cultured brain neurons: roles in glutamate excitotoxicity and lithium neuroprotection. J Neurochem 84:566-575.

Copani A, Sortino MA, Caricasole A, Chiechio S, Chisari M, Battaglia G, Giuffrida-Stella AM, Vancheri C, Nicoletti F (2002) Erratic expression of DNA polymerases by beta-amyloid causes neuronal death. FASEB J 16:2006-2008.

Cotter D, Kerwin R, al-Sarraji S, Brion JP, Chadwick A, Lovestone S, Anderton B, Everall I (1998) Abnormalities of Wnt signaling in schizophrenia-evidence for neurodevelopmental abnormality. NeuroReport 9:1379-1383.

Dale TC (1998) Signal transduction by the Wnt family of ligands. Biochem J 329:209-223.

Dean B (2002) Understanding the pathology of schizophrenia: recent advances from the study of the molecular architecture of postmortem CNS tissue. Postgrad Med J 78:142-148.

De Ferrari GV, Inestrosa NC (2000) Wnt signaling function in Alzheimer's disease. Brain Res Brain Res Rev 33:1-12. 

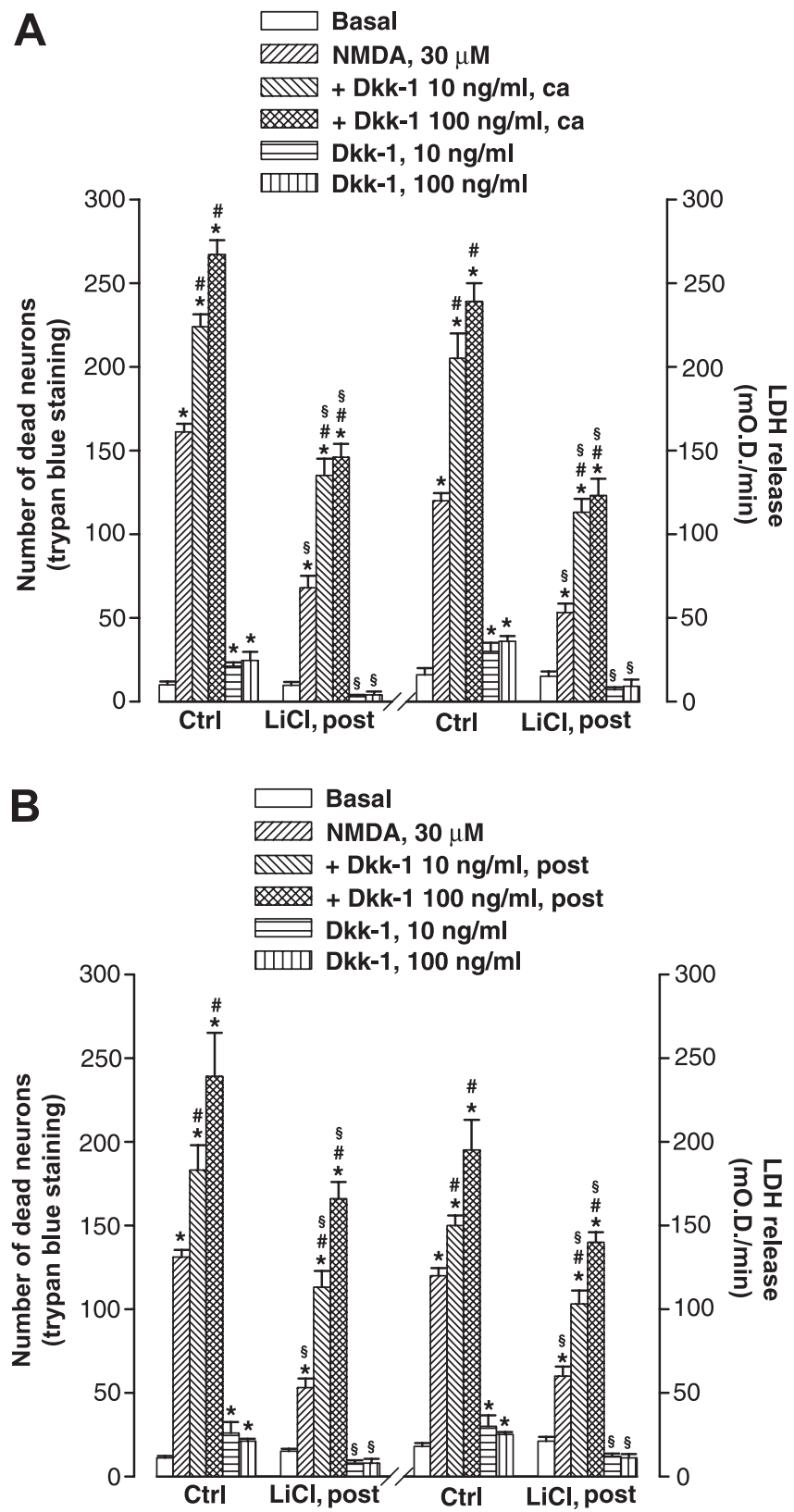

Figure 9. Neuronal degeneration induced by exogenous application of human recombinant Dkk-1 applied alone for 10 min or combined with NMDA during the excitotoxic pulse is shown in A. Ctrl, Control. The effect of exogenous Dkk-1 applied immediately after the NMDA pulse and maintained in the medium for the next $24 \mathrm{~h}$ (or applied for $24 \mathrm{~h}$ in cultures that were not challenged with NMDA) is shown in $\boldsymbol{B}$. The effect of exogenous Dkk-1 on neuronal death in cultures treated with LiCl $(10 \mathrm{~mm})$, added immediately after the NMDA pulse, is also shown. Neuronal death was assessed $24 \mathrm{~h}$ after the NMDA pulse. Values are mean \pm SEM of six determinations and are expressed as number of dead neurons (from 3 microscopic fields/well) and as LDH released in the culture medium from damaged or dead neurons. $p<0.05$; one-way ANOVA plus Fisher's PLSD versus basal conditions $\left({ }^{*}\right)$, NMDA alone (\#), or the respective values obtained in the absence of lithium (§).

De Ferrari GV, Chacon MA, Barria MI, Garrido JL, Godoy JA, Olivares G, Reyes AE, Alvarez A, Bronfman M, Inestrosa NC (2003) Activation of Wnt signaling rescues neurodegeneration and behavioral impairments induced by $\beta$-amyloid fibrils. Mol Psychiatry 8:195-208.

Frame S, Cohen P, Biondi RM (2001) A common phosphate binding site explains the unique substrate specificity of GSK3 and its inactivation by phosphorylation. Mol Cell 7:1321-1327.

Fukumoto S, Hsieh CM, Maemura K, Layne MD, Yet SF, Lee KH, Matsui T, Rosenzweig A, Taylor WG, Rubin JS, Perrella MA, Lee ME (2001) Akt participation in the Wnt signaling pathway through Dishevelled. J Biol Chem 276:17479-17483.

Garrido JL, Godoy JA, Alvarez A, Bronfman M, Inestrosa NC (2002) Protein kinase $C$ inhibits amyloid $\beta$ peptide neurotoxicity by acting on members of the Wnt pathway. FASEB J 16:1982-1984.

Glinka A, Wu W, Delius H, Monaghan AP, Blumenstock C, Niehrs C (1998) Dickkopf- 1 is a member of a new family of secreted proteins and functions in head induction. Nature 391:357-362.

Grimes CA, Jope RS (2001) CREB DNA binding activity is inhibited by glycogen synthase kinase- $3-\beta$ and facilitated by lithium. J Neurochem 78:1219-1232.

Grotewold L, Ruther U (2002a) Bmp, Fgf and Wnt signaling in programmed cell death and chondrogenesis during vertebrate limb development: the role of Dickkopf-1. Int J Dev Biol 46:943-947.

Grotewold L, Ruther U (2002b) The Wnt antagonist Dickkopf-1 is regulated by Bmp signaling and c-Jun and modulates programmed cell death. EMBO J 21:966-975.

Hart MJ, de los Santos R, Albert IN, Rubinfeld B, Polakis P (1998) Downregulation of $\beta$-catenin by human Axin and its association with the APC tumor suppressor, $\beta$-catenin and GSK3 $\beta$. Curr Biol 8:573-581.

Hashimoto M, Sagara Y, Langford D, Everall IP, Mallory M, Digicaylioglu M, Masliah E (2002) Fibroblast growth factor 1 regulates signaling via the glycogen synthase kinase- $3 \beta$ pathway. Implications for neuroprotection. J Biol Chem 277:32985-32991.

Hashimoto R, Hough C, Nakazawa T, Yamamoto T, Chuang DM (2002a) Lithium protection against glutamate excitotoxicity in rat cerebral cortical neurons: involvement of NMDA receptor inhibition possibly by decreasing NR2B tyrosine phosphorylation. J Neurochem 80:589-597.

Hashimoto R, Takei N, Shimazu K, Christ L, Lu B, Chuang DM (2002b) Lithium induces brain-derived neurotrophic factor and activates TrkB in rodent cortical neurons: an essential step for neuroprotection against glutamate excitotoxicity. Neuropharmacology 43:1173-1179.

Hashimoto R, Fujimaki K, Jeong MR, Christ L, Chuang DM (2003) Lithium-induced inhibition of Src tyrosine kinase in rat cerebral cortical neurons: a role in neuroprotection against $N$-methyl-D-aspartate receptor-mediated excitotoxicity. FEBS Lett 538:145-148.

Hetman M, Cavanaugh JE, Kimelman D, Xia Z (2000) Role of glycogen synthase kinase- $3 \beta$ in neuronal apoptosis induced by trophic withdrawal. J Neurosci 20:2567-2574.

Hinck L, Nelson WJ, Papkoff J (1994) Wnt-1 modulates cell-cell adhesion in mammalian cells by stabilizing $\beta$-catenin binding to the cell adhesion protein cadherin. J Cell Biol 124:729-741.

Hofseth LJ, Hussain SP, Harris CC (2004) p53: 25 years after its discovery. Trends Pharmacol Sci 25:177-181.

Howng SL, Wu CH, Cheng TS, Sy WD, Lin PC, Wang C, Hong YR (2002) Differential expression of Wnt genes, $\beta$-catenin and E-catherin in human brain tumors. Cancer Lett 183:95-101.

Inestrosa N, De Ferrari GV, Garrido JL, Alvarez A, Olivares GH, Barria MI, Bronfman M, Chacon MA (2002) Wnt signaling involvement in $\beta$-amyloid-dependent neurodegeneration. Neurochem Int 41:341-344.

Kawano Y, Kypta R (2003) Secreted antagonists of the Wnt signalling pathway. J Cell Sci 116:2627-2634.

Kelly S, Zhao H, Hua Sun G, Cheng D, Qiao Y, Luo J, Martin K, Steinberg GK, Harrison SD, Yenari MA (2004) Glycogen synthase kinase $3 \beta$ inhibitor Chir025 reduces neuronal death resulting from oxygen-glucose deprivation, glutamate excitotoxicity, and cerebral ischemia. Exp Neurol 188:378-386

Kim HS, Kim EM, Lee JP, Park CH, Kim S, Seo JH, Chang KA, Yu E, Jeong SJ, Chong YH, Suh YH (2003) C-terminal fragments of amyloid precursor protein exert neurotoxicity by inducing glycogen synthase kinase- $3 \beta$ expression. FASEB J 17:1951-1953.

Levina E, Oren M, Ben-Ze'ev A (2004) Downregulation of $\beta$-catenin and p53 involves changes in the rate of $\beta$-catenin phosphorylation and Axin dynamics. Oncogene 23:4444-4453.

Ma J, Zhang GY, Liu Y, Yan JZ, Hao ZB (2004) Lithium suppresses Tyr-402 phosphorylation of proline-rich tyrosine kinase $(\mathrm{Pyk} 2)$ and interactions of Pyk2 and PSD-95 with NR2A in rat hippocampus following cerebral ischemia. Neurosci Res 49:357-362.

Mailliot C, Podevin-Dimster V, Rosenthal RE, Sergeant N, Delacourte A, Fiskum G, Buee L (2000) Rapid tau protein dephosphorylation and differential rephosphorylation during cardiac arrest-induced cerebral ischemia and reperfusion. J Cereb Blood Flow Metab 20:543-549. 
Mao B, Wu W, Davidson G, Marhold J, Li M, Machler BM, Delius H, Hoppe D, Stannek P, Walter C, Glinka A, Niehrs C (2002) Kremen proteins are Dickkopf receptors that regulate Wnt/ $\beta$-catenin signalling. Nature 17:664-667.

McGahan L, Hakim AM, Robertson GS (1998) Hippocampal Myc and p53 expression following transient global ischemia. Brain Res Mol Brain Res 56:133-145

Miyaoka T, Seno H, Ishino H (1999) Increased expression of Wnt-1 in schizophrenic brains. Schizophr Res 38:1-6.

Mukhopadhyay M, Shtrom S, Rodriguez-Esteban C, Chen L, Tsukui T, Gomer L, Dorward DW, Glinka A, Grinberg A, Huang SP, Niehrs C, Belmonte JC, Westphal H (2001) Dickkopf1 is required for embryonic head induction and limb morphogenesis in the mouse. Dev Cell 1:423-434.

Murase S, Mosser E, Schuman EM (2002) Depolarization drives $\beta$-catenin into neuronal spines promoting changes in synaptic structure and function. Neuron 35:91-105.

Nonaka S, Chuang DM (1998) Neuroprotective effects of chronic lithium on focal cerebral ischemia in rats. NeuroReport 9:2081-2084.

Nonaka S, Hough CJ, Chuang DM (1998) Chronic lithium treatment robustly protects neurons in the central nervous system against excitotoxicity by inhibiting $N$-methyl-D-aspartate receptor-mediated calcium influx. Proc Natl Acad Sci USA 95:2642-2647.

Pulsinelli WA, Brierley JB (1979) A new model of bilateral hemispheric ischemia in the unanaesthetized rat. Stroke 10:267-272.

Roelen BA, Lin YH, Knezevic V, Freund E, Mummery CL (1994) Expression of TGF-betas and their receptors during implantation and organogenesis of the mouse embryo. Dev Biol 166:716-728.

Rose K, Goldberg MP, Choi DW (1992) Cytotoxicity in murine neocortical cell culture. In: Methods in toxicology, $\mathrm{Vol} 1$, In vitro biological systems (Tyson CA, Frazier JM, eds), pp 46-60. San Diego: Academic.

Senatorov VV, Ren M, Kanai H, Wei H, Chuang DM (2004) Short-term lithium treatment promotes neuronal survival and proliferation in rat striatum infused with quinolinic acid, an excitotoxic model of Huntington's disease. Mol Psychiatry 9:371-385.

Shackelford DA, Yeh RY (1998) Dephosphorylation of tau during transient forebrain ischemia in the rat. Mol Chem Neuropathol 34:103-120.

Shou J, All-Osman F, Multani AS, Pathak S, Fedi P, Srivenugopal KS (2002) Human Dkk-1, a gene encoding a Wnt antagonist, responds to DNA damage and its overexpression sensitizes brain tumor cells to apoptosis following alkylation damage of DNA. Oncogene 21:878-889.

Slee EA, O'Connor DJ, Lu X (2004) To die or not to die: how does p53 decide? Oncogene 23:2809-2818.

Tanaka H, Yokota H, Jover T, Cappuccio I, Calderone A, Simionescu M, Bennet MV, Zukin RS (2004) Ischemic preconditioning: neuronal survival in the face of caspase-3 activation. J Neurosci 24:2750-2759.

Tomasevic G, Shamloo M, Israeli D, Wieloch T (1999) Activation of p53 and its target genes p21(WAF1/Cip1) and PAG608/Wig-1 in ischemic preconditioning. Brain Res Mol Brain Res 70:304-313.

Wang J, Shou J, Chen X (2000) Dickkopf-1, an inhibitor of the Wnt signaling pathway, is induced by p53. Oncogene 19:1843-1848.

Wassink TH, Piven J, Vieland VJ, Huang J, Swiderski RE, Pietila J, Braun T, Beck G, Folstein SE, Haines JL, Sheffield VC (2001) Evidence supporting WNT2 as an autism susceptibility gene. Am J Med Genet 105:406-413.

Wei H, Qin ZH, Senatorov VV, Wei W, Wang Y, Qian Y, Chuang DM (2001) Lithium suppresses excitotoxicity-induced striatal lesions in a rat model of Huntington's disease. Neuroscience 106:603-612.

Willert K, Nusse R (1998) $\beta$-Catenin: a key mediator of Wnt signaling. Cur Opin Genet Dev 8:95-102.

Xu J, Culman J, Blume A, Brecht S, Gohlke P (2003) Chronic treatment with a low dose of lithium protects the brain against ischemic injury by reducing apoptotic death. Stroke 34:1287-1292.

Zorn AM (2001) Wnt signaling: antagonistic Dickkopf. Curr Biol 11:R592R595. 